Yet teamwork, technology and business sense are essential for the survival of the British economy.

But what if you cannot even bring the horse to the water, let alone persuade him to drink properly ? The symposium depressed itself with speculation about the reasons why young people may now be reluctant to go in for science and technology. Again there seemed to be general agreement that the young are infected with a "new fatalism" and have no vision of a golden future to which science and technology may contribute and no inkling of the enthusiasm which professional scientists have for their work. It was all good gloomy stuff. One of these days something may be done about it.

\section{Instant Teachers}

How long does it take to turn a student of the humanities into a science teacher? Three years is the answer given by Nottingham Regional College of Technology. In its new Department of Education, Nottingham is basing its acceptance of candidates for its three year Certificate of Education course in science teaching on general ability and interest in science teaching as well as academic qualifications in science. Thus if a candidate can demonstrate his ability in other subjects and his interest in science teaching, the college will accept him even if he does not know one end of a thermometer from the other.

Because of the shortage in applications from science candidates to teacher training colleges and universities, the department has decided not to compete for pure scientists but to offer Applied Science and a second opportunity to those who opted for the humanities instead of science at school. As the courses are designed for the Nuffield programme of science teaching, where a feel for the subject is much more important than facts, it is hoped that general ability will make up for any lack of specific knowledge.

The courses will tend towards either Biological Sciences or Physical Sciences and an Engineering course is under discussion. The students of the physical seiences will spend four terms working on American courses, which start from first principles for beginners but allow scientists to be rapidly directed into more profitable work. The teaching scheme is based on individual study rather than lecture programmes, and tutors will make much use of written material, acting as directors of study and tailoring the work to each student's needs. Students will also be able to take short courses from a range which will include Computer Science, Chemical Technology, Building Science, Food Science, Materials Science and Mechanical Engineering. These short courses should enable the students to base their teaching on practical applications when they go into the schools.

Nottingham Regional College of Technology is one of five technical colleges-the others are John Dalton College, Manchester, Sunderland Technical College, Barking Regional College of Technology and North Western Polytechnic-which are now running courses for the Certificate of Education. Previously these three year courses could only be taken at Colleges of Education. The Principal Lecturer, in charge of the science courses at Nottingham, is Dr Michael Bassey, who will be remembered for his trenchant criticisms of school science syllabuses at the British Association. meeting in 1961 .

\section{More Cancer Research}

A NEW research block consisting of laboratories for Tumour Immunology and Radiobiology was opened at Sutton, Surrey, on September 27. The unit is part of the Chester Beatty Research Institute, and the $£ 150,000$ it cost has come from the Napier Trust, the British Empire Cancer Campaign, the Medical Research Council and other donations. Block X, as it is called, has been operational since June, only 17 months after the idea for such a unit was suggested. Because the unit is alongside the Sutton branch of the Royal Marsden Hospital, it is hoped that any positive results that are obtained will be speedily applied.

Work has been going on for some time on various forms of immunotherapy, and in particular the treatment of primary sarcomata by injection of either immunized lymphocytes or of immunized cancer cells, that is, cells taken from the tumour, after removal by surgery, and rendered "sterile" by irradiation. Some of the impetus for the new research unit has come from research described earlier this year by Alexander, Delorme, Hamilton and Hall (Nature, 213, 569). Evidence has been found in animals of host resistance to tumours, and it is hoped that by boosting this reaction by the injection of immune lymphocytes it will be possible to provide some control. This form of treatment would be particularly important after surgery.

Under some conditions this treatment has proved successful in experimental animals, but it is emphasized by the staff of the new unit that experience of this treatment is too limited for any definite conclusions to be drawn. The mechanism of the cytotoxic action of lymphocytes is also being studied.

American workers S. H. Nadler and G. E. Moore have also carried out transplant experiments in which tumours from two patients were transplanted to each other and after 10-14 days lymphocytes from each patient were transfused back to the other to fight the original growth. In several cases remission of the cancer for considerable lengths of time has occurred. This method of treatment is also being considered for investigation at the new unit.

\section{Refining Steel}

Electro-slat Refining Technology, the British Iron and Steel Research Association's first development unit which was formed to exploit the electro-slag refining process, has fully justified its existence in its 15 months of operation on a commercial basis. It has recorded widespread use of its hire and contract facilities and has been responsible for a number of technical developments. Five plant manufacturers have entered into agreements with ESRT, and have installed or are installing fourteen plants with ingot producing capacities ranging from 8 to 36 in. The unit has also supplied 250 ingots to some twenty-five customers, covering a range of thirty-five alloys. The ingots have enabled customers to evaluate the electroslag refining process. 224 ingots have been made on a miniature plant in thirty-eight individual contract evaluation programmes for fourteen clients. As a result of these studies, techniques have been developed for production melting of many alloys both in Britain and overseas.

Electro-slag refining is a secondary refining process 